Paper

\title{
Effects of utilization of water extract from coffee grounds on the growth and chlorophyll content of Japanese mustard spinach
}

コーヒー粕水抽出液の施用がコマツナの生育およびクロロフィル含有量に及ぼす影響

\author{
Anna ISHIZUKA \\ Course of Human Environmental Studies, Graduate school of Human Environmental Studies, Tokai \\ University, 4-1-1 Kitakaname, Hiratsuka, Kanagawa, 259-1292 Japan \\ TEL: +81-463-58-1211(EX.3411) FAX: +81-463-50-2208 e-mail: 6bhlm001@mail.u-tokai.ac.jp \\ Keiko ISHIHARA \\ Center for Liberal Arts, Tokai University, 4-1-1 Kitakaname, Hiratsuka, Kanagawa, 259-1292 Japan \\ TEL: +81-463-58-1211(EX.4816) FAX: +81-463-50-2208 e-mail: keiko.I@tsc.u-tokai.ac.jp
}

\begin{abstract}
Kenichi MUROTA
Department of Human Development, School of Humanities and Culture, Tokai University, 4-1-1 Kitakaname, Hiratsuka, Kanagawa, 259-1292 Japan

TEL: +81-463-58-1211(EX.3411) FAX: +81-463-50-2208 e-mail: murota@tokai.ac.jp
\end{abstract}

(Received 6 June, $2018 \quad$ Accepted 25 January, 2019)

\begin{abstract}
We are investing effective utilization of the food wastes for agriculture and focusing on coffee grounds which is disposed of in a large quantity and difficult to reuse. There are obstacles in using coffee grounds for agricultural materials, because coffee grounds are high carbon to nitrogen $(\mathrm{C} / \mathrm{N})$ ratio and may contain a kind of plant growth inhibitor, therefore here we used water extract from coffee grounds. Growth of Japanese mustard spinach (Brassica rapa var. prviridis) was enhanced by applying the water extract from coffee grounds, and the growth ratio was almost the same as plants applied commercial liquid fertilizer. The water extract from coffee grounds showed higher values in nitrogen, phosphoric acid, potassium, and minerals than the commercial liquid fertilizer, the plants, however, might not use these nutrients enough. Chlorophyll content in the plants applied the water extract from coffee grounds was higher than plants applied the liquid fertilizer, but there was no correlation between chlorophyll content and growth of plants.
\end{abstract}

Keywords : Agriculture, Food waste, Coffee grounds

\section{INTRODUCTION}

I-A. Effect of coffee grounds on plant growth コーヒー粕は、国内で年間約 90 万トン廃棄されてい ると推定され、生ゴミとは異なり形状が均質であること や通気性が優れていることから、農業資材として比較的 利用しや寸い素材であるとされている。1 コーヒー粕と

SAS Award was given to this paper presented as Poster Presentation at the 2017 SAS Symposium.
オカラとを混合させることにより良質な堆肥となること や、牛糞、紅茶粕等との混合による肥料化が報告がされ ている。2,3 しかしながら、コーヒー粕の施用によって植 物の生育阻害が起こることが明らかにされていることか ら、コーヒー粕そのものの農業利用は困難とされている。 その原因としては、コーヒー粕の炭素/窒素 $(\mathrm{C} / \mathrm{N})$ 比が 比較的高く、窒素成分のほとんどが難溶解性の画分に含 まれており、微生物および植物に利用されにくい形態で あることや、植物の生育阻害物質の存在が示唆されてい 
る。 4,5

そこで、我々はコーヒー粕そのもののではなく、コー ヒ一粕の水抽出液（抽出液）の農業利用に着目した。こ れまでに、抽出液の施用がコマツナの生育に及ぼす影響 を調べた結果、抽出液の施用によりコマツナの生育が市 販の液体肥料と比較して良好な結果を示した。その原因 としてはコーヒー粕そのものの中には植物の生育に必要 な肥料成分が含まれていることから、それらの成分の関 与が示唆された。また、抽出液施用により葉の緑色が濃 くなることが観察されたことから、葉のクロロフィルの 含有量と生長促進との関係が示唆されたが、これらにつ いては明らかになっていない。6

そこで本研究では、その生育促進の原因を明らかにす る目的で、抽出液中の肥料成分の含有量および葉のクロ ロフィル含有量を調べ、抽出液がコマツナの生育に及ぼ す影響を考察した。

\section{METHODS AND MATERIALS}

\section{II-A. Water extract from coffee grounds}

コーヒー粕はドトールコーヒーショップ東海大学店よ り供与されたものを使用した。コーヒー粕は使用前にド ライングオーブン $\left(50^{\circ} \mathrm{C} 、 42 \mathrm{hrs}\right)$ で乾燥させたものを蒸 留水 (コーヒー粕 $150 \mathrm{~g}$ : 蒸留水 $600 \mathrm{ml}$ ) とともに 10 分 間攪拌後、ろ紙にてろ過したものを抽出液として使用し た。

\section{II-B. Methods}

供試植物はコマツナ（Brassica rapa var.perviridis）を用 いた。試験区は、蒸留水を施用したコントロール区、市 販の液体肥料であるハイポネックス（Hyponex ${ }^{\circledR}$ $(\mathrm{N}: \mathrm{P}: \mathrm{K}=6: 10: 5))$ の 1,000 倍希橎液を 1 回/週施用（通常 作物栽培に利用する際の希勫率および施用頻度）した「八 イポネックス区」、抽出液を施用開始 1 週目に 3 回/週、 施用開始 2 週目に 4 回/週施用した「抽出液多施用区（多 施用区）（図表中：Many）」、抽出液を施用開始 1 週目に 1 回/週、2 週目から 2 回/週施用した「抽出液少施用区 （少施用区）（図表中:Few」の 4 試験区を設定した。 植物体は、直径 $7.5 \mathrm{~cm} \times$ 高さ $6.5 \mathrm{~cm}$ のプラスチックポ ットにバーミキュライトを充填したものに 2 粒/ポット で 10 ポット播種し、人工気象器 $\left(26^{\circ} \mathrm{C}\right.$ 、明期: 暗期 $=12: 12$ hrs）を用いて栽培した。ハイポネックス 1,000 倍希釈液 および抽出液の施用は、本葉の展開が全試験区で確認さ れた播種後 16 日目から開始した。施用量は $30 \mathrm{ml}$ とし、 収穫後にクロロフィルの抽出・定量を Mackinney 法 ${ }^{7}$ に より行い、それぞれの測定結果は ANOVAによる分散分 析および Ryan 法による多重比較により解析した。また、 抽出液の肥料成分分析は株式会社環境分析センター一依 頼した。

\section{RESULTS AND DISCUSSION}

これまでに、抽出液の施用によるコマツナの生育を調 ベた結果、生体重は平均值でコントロール区が $0.416 \mathrm{~g}$ 、 ハイポネックス区が $0.818 \mathrm{~g}$ であったのに対し、抽出液多 施用区が $0.957 \mathrm{~g}$ で、ハイポネックス区に比べて有意に高 い值を示した。一方少施用区では $0.526 \mathrm{~g}$ でコントロール 区よりも有意に高い值を示したものの、ハイポネックス 区に比べて有意に低い值を示した。このことから、抽出 液の施用はコマツナの生育を促進し、その程度は施用回 数が多くなるほど大きくなることがわかった (Table 1)。6

Table 1. Fresh weight (g). Letter indicate significant differences among means between treatments, according to analysis of variance and Ryan's method $(\mathrm{P}<0.01)$. It has been already published in reference 6 .

\begin{tabular}{|c|c|c|c|}
\hline Control & Hyponex & $\begin{array}{c}\text { Coffee grounds } \\
\text { (Few) }\end{array}$ & $\begin{array}{c}\text { Coffee grounds } \\
\text { (Many) }\end{array}$ \\
\hline 0.416 & 0.818 & 0.526 & 0.957 \\
\pm 0.008 (a) & \pm 0.018 (b) & $\pm 0.016(\mathrm{c})$ & \pm 0.044 (d) \\
\hline
\end{tabular}

抽出液施用によるコマツナの生育促進の原因を明らか にするために、抽出液中の肥料成分の分析を行った

(Table 2)。その結果、抽出液中には植物の生育に対する 多量必須元素である窒素 $(\mathrm{N})$ が $390 \mathrm{mg} / \mathrm{L} 、$ リン酸 $\left(\mathrm{P}_{2} \mathrm{O}_{5}\right)$ が $360 \mathrm{mg} / \mathrm{L}$ 、カリウム $(\mathrm{K})$ が $830 \mathrm{mg} / \mathrm{L}$ であった。本研 究で使用したハイポネックス 1,000 倍希釈液は窒素が 60 $\mathrm{mg} / \mathrm{L}$ 、リン酸が $100 \mathrm{mg} / \mathrm{L}$ 、カリウムが $50 \mathrm{mg} / \mathrm{L}$ であるこ とから、いずれもハイポネックス 1,000 倍希釈液よりも 高い值を示していた。微量元素についても、ハイポネッ クス 1,000 倍希釈液中のマグネシウム $(\mathrm{Mg})$ が $0.5 \mathrm{mg} / \mathrm{L}$ やマンガン $(\mathrm{Mn})$ が $0.01 \mathrm{mg} / \mathrm{L}$ であるのに対し、抽出液 ではそれぞれ $120 \mathrm{mg} / \mathrm{L} 、 1.6 \mathrm{mg} / \mathrm{L}$ と高い值を示した。ま た、先行研究よりコーヒー粕そのものの $\mathrm{C} / \mathrm{N}$ 比が約 24 である ${ }^{5}$ のに対して、抽出液では約 14 でコーヒー粕より も低い值を示した。 $\mathrm{C} / \mathrm{N}$ 比の大きな農業資材を围場に施 用すると一時的に植物が窒素を利用しにくくなる窒素飢 餓の状態になることがわかっている。このことから、肥 料として利用する場合、コーヒー粕そのものに比べて抽 出液を施用した方が、植物が比較的窒素を利用しやすい 環境になるといえる。8

Table 2. Content of total nitrogen, phosphorus, total carbon and minerals in water extract from coffee grounds $(\mathrm{mg} / \mathrm{L})$.

\begin{tabular}{|c|c|c|c|c|}
\hline $\mathrm{N}$ & $\mathrm{P}_{2} \mathrm{O}_{5}$ & $\mathrm{C}$ & $\mathrm{K}$ & $\mathrm{Ca}$ \\
\hline 390 & 360 & 5,300 & 830 & 49 \\
\hline $\mathrm{Mg}$ & $\mathrm{Zn}$ & $\mathrm{Fe}$ & $\mathrm{Cu}$ & $\mathrm{Mn}$ \\
\hline 120 & 0.14 & 0.10 & 0.09 & 1.6 \\
\hline
\end{tabular}


抽出液区とハイポネックス区で栽培期間中に施用した 肥料成分量を算出した（Table 3）。窒素では多施用区で八 イポネックス区の約 23 倍、リン酸では約 13 倍、カリウ ムでは約 58 倍の成分を施用したことになる。また、少施 用区でもそれぞれ約 10 倍、5 倍、25 倍であった。生体重 では多施用区は八イポネックス区に比べて有意に高い值 を示したものの、少施用区では八イポネックス区に比べ て有意に低い值を示した。また抽出液の多施用区でハイ ポネックス区を上回る生育を示したことから、本研究で 使用した抽出液に含まれる肥料成分量では肥料の過剩症 の影響は小さいと考えられた。これらのことから、抽出 液中の肥料成分はコマツナの生育に十分に利用されてい ないことが示唆された。抽出液区で肥料成分量に見合っ た生育を示さなかった原因として、抽出液中の肥料成分 が十分に利用できなかったことに加えて、先行研究 4,5 で 指摘されている生育阻害因子の関与が示唆された。

Table 3. Total amount of nutrition which applied dose in water extract from coffee grounds and Hyponex $(1,000 \mathrm{x}$ dilution) (mg).

\begin{tabular}{|c|r|r|r|}
\hline \multirow{2}{*}{ Element } & \multicolumn{2}{|c|}{ Coffee grounds } & \multicolumn{1}{c|}{$\begin{array}{c}\text { Hyponex } \\
(1,000 \mathrm{x} \\
\text { dilution })\end{array}$} \\
\cline { 2 - 3 } & \multicolumn{1}{|c|}{ Few } & \multicolumn{1}{c|}{ Many } & 3.60 \\
\hline \hline $\mathrm{N}$ & 35.1 & 81.9 & 6.00 \\
\hline $\mathrm{P}$ & 32.4 & 75.6 & 3.00 \\
\hline $\mathrm{K}$ & 74.7 & 174 & \\
\hline
\end{tabular}

次にそれぞれの試験区のクロロフィル含有量を調べた。 クロロフィルは光合成系で機能する色素であり、葉緑体 のチラコイド膜に局在し、光エネルギーの吸収と光化学 反応中心分子への励起エネルギー伝達、光化学反応中心 分子での電子移動反応の駆動に関与している。クロロフ イルが不足すると光合成が効率よく行われないことで、 植物の生育に影響を与える。9,10

クロロフィル $\mathrm{a}+\mathrm{b}$ では、平均值がコントロール区で $0.194 \mathrm{mg} / \mathrm{g}$ であり、ハイポネックス区では $0.620 \mathrm{mg} / \mathrm{g}$ で あったのに対し、少施用区で $1.046 \mathrm{mg} / \mathrm{g}$ 、多施用区で 1.022 $\mathrm{mg} / \mathrm{g}$ と抽出液少施用区および多施用区がハイポネックス 区に比べて有意に高い值を示した（Figure 1)。また、クロ ロフィル a および b のそれぞれの含有量についても同様 に抽出液少施用区および多施用区がハイポネックス区に 比べて有意に高い值を示した（Figure 2,3）。

窒素の施用量および葉内窒素の増加により葉のクロロ フィル含有量が増加することがわかっている。11,12 本研 究においてもクロロフィルの含有量は抽出液の施用によ り増加したことから、抽出液中の窒素がその原因になっ ていると考えられた。しかしながら、その増加量は抽出 液の施用回数、すなわち総施用量とは相関が見られない ことから、クロロフィルの合成に用いられる窒素は限定 的であることがわかった。また、抽出液少施用区の生体
重はハイポネックス区に比べて有意に低い值を示したこ とから、抽出液施用によるクロロフィル含有量とコマツ ナの生長には相関が見られなかった。

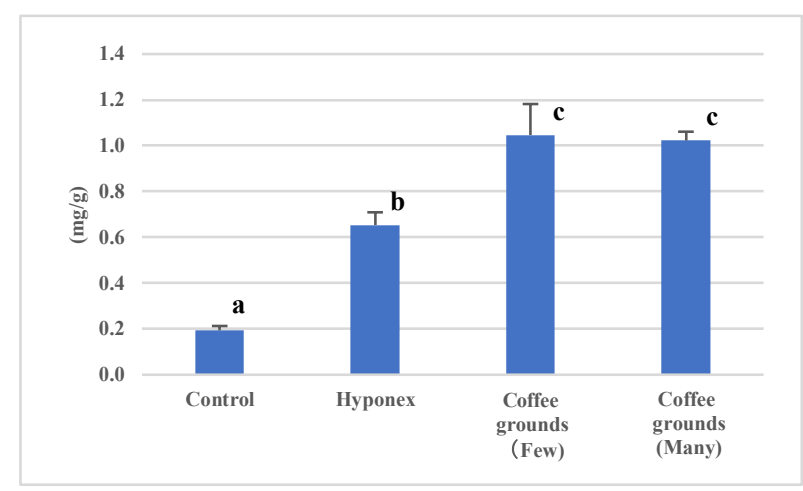

Figure 1. Chlorophyll $\mathrm{a}+\mathrm{b}$ content. Letter above columns indicate significant differences among means between treatments, according to analysis of variance and Ryan's method $(\mathrm{P}<0.01)$.

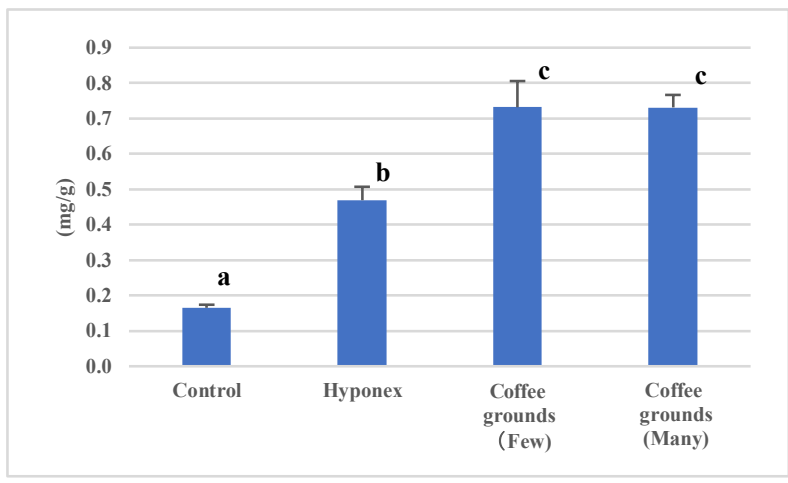

Figure 2. Chlorophyll a content. Letter above columns indicate significant differences among means between treatments, according to analysis of variance and Ryan's method $(\mathrm{P}<0.01)$.

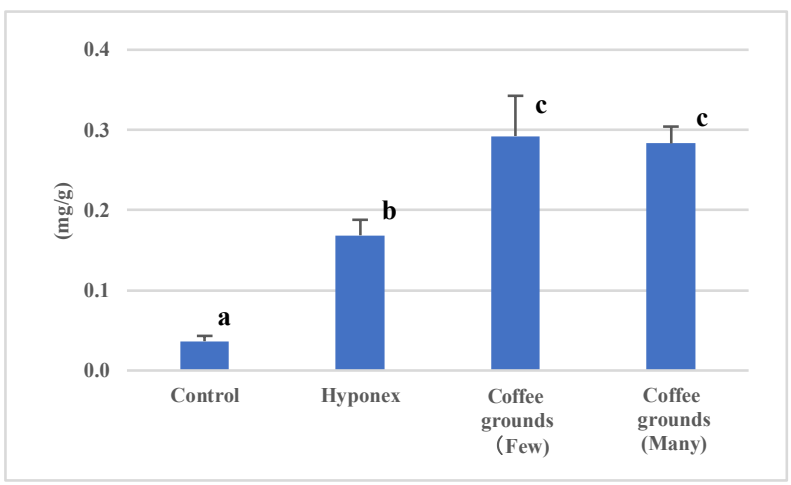

Figure 3. Chlorophyll b content. Letter above columns indicate significant differences among means between treatments, according to analysis of variance and Ryan's method $(\mathrm{P}<0.01)$. 


\section{CONCLUSION}

食品廃棄物としてその廃棄量が増加傾向にあるコーヒ 一粕を有効に利用する方法として農業資材としての利用 が研究されている。先行研究より、コーヒー粕そのもの は作物生産への利用が困難であることが報告されている ことから、抽出液に着目して、その施用がコマツナの生 育に及ぼす影響を調べた。その結果、抽出液の施用によ り市販の液体肥料であるハイポネックス施用と同等ある いはそれを上回る生育を示した。そこで本研究では、抽 出液施用による生育促進の原因を明らかにする目的で、 抽出液の肥料成分を分析するとともに、抽出液施用が葉 のクロロフィル含有量におよぼす影響を調べた。

その結果、抽出液中には多量必須元素である窒素、リ ン酸、カリウムをはじめとして、その他の肥料成分であ る元素も多量に含まれていることがわかった。抽出液施 用によるコマツナの生育促進は、この豊富な肥料成分の 影響であると考えられたが、その成分が十分に利用され ないことが示唆された。葉中のクロロフィル含有量は抽 出液の施用により増加することがわかった。窒素の施用 によりクロロフィル含有量が増加することがわかってい るが、本研究ではクロロフィル生合成に対する窒素の利 用は限定的であり、クロロフィル含有量とコマツナの生 長には相関が見られないことがわかった。

\section{REFERENCES}

1 INTERNATIONAL COFFEE ORGANIZATION: http://coffee.ajca.or.jp (2018).
2 S. Fujiwara, M. Takemoto and H. Takeda, Bulletin of the Agricultural Research Institute of Kanagawa Prefecture, 137, pp. 43-50 (1996) (in Japanese).

3 Y. Umemiya, S. Yoshida, K. Yamada, T. Murakami, Journal of the science of soil and manure, 42, p. 33 (1996) (in Japanese).

4 H. Wakasawa, K. Takahashi and K. Mochizuki, Journal of the science of soil and manure, 69, pp.16 (1998) (in Japanese).

5 M. Takemoto and S. Fujiwara, Bulletin of the Agricultural Research Institute of Kanagawa Prefecture, 138, pp. 31-40 (1997) (in Japanese).

6 A. Ishizuka, K. Ishihara and K. Murota, Journal of Advanced Science, 29, pp. 1-5 (2017) (in Japanese).

7 G. Mackinney, Journal of Biological Chemistry, 140, pp. 315-322 (1941).

8 Su. Aso, Sh. Aso and T. Matsuzaki, Sakumotsu no eiyou to hiryou, (1973) p. 149 (in Japanese).

9 M. Mimuro, T. Kakitani, H. Tamiaki, Chlorophylls - Structure, Reaction and Function -, (Shokabo, 2011) p. 137 (in Japanese).

${ }^{10}$ A. Tanaka, M. Hirashima, R. Tanaka, Kagaku to seibutsu, 42, pp. 93-98 (2004) (in Japanese).

${ }^{11}$ N. Nii, K. Yamaguchi, M. Nishimura, J. Japan. Soc. Hort. Sci, 66, pp. 505-511 (1997).

12 T. Shimizu, H. Torigata, J. Japan. Soc. Hort. Sci, 41, pp. 29-36 (1972) (in Japanese). 